\title{
Classrooms for Consumer Society: Practical Education and Secondary School Reform in Post-Second World War Canada
}

\author{
Katharine Rollwagen \\ Vancouver Island University
}

\begin{abstract}
Young people's intersecting roles as students, workers, and shoppers have received little attention from historians, who have focused on young people as either students or workers. This paper begins to examine these roles by analyzing the efforts of the Canadian Education Association to define and promote practical education in the late 1940s. The Canadian Research Committee on Practical Education solicited industry and business perspectives and surveyed students who were leaving school before graduation. The committee's work and the discussion it generated reveal a desire to make secondary schools more profitable and palatable for Canadian teenagers. Educators and industry leaders wanted the post-war high school to serve all young Canadians by catering to their interests, keeping them in school, and preparing them to be both workers and consumers upon graduation.
\end{abstract}

\section{RÉSUMÉ}

Les jeunes comme groupe peuvent se définir selon trois caractéristiques : élèves, travailleurs et consommateurs. Cette façon de concevoir la jeunesse n'a reçu que peu d'attention de la part des historiens. Ces derniers ont étudié les jeunes soit comme élèves ou soit comme travailleurs. Cet article s'intéresse à ces trois caractéristiques en s'intéressant aux actions entreprises par l'Association canadienne d'éducation. L'auteure analyse les efforts de cette dernière pour définir et promouvoir les arts et métiers en éducation à la fin des années 1940. Le Comité de recherche canadien sur l'éducation pratique a sollicité l'aide des industries et des maisons d'affaires pour recenser les élèves qui quittaient l'école avant la fin de leurs études. Le travail du comité et les discussions qui s'ensuivirent ont révélé le besoin de rendre les écoles secondaires plus utiles et plus attirantes pour les adolescents canadiens. Les éducateurs et les chefs d'entreprises souhaitaient que l'école secondaire d'après-guerre soit utile aux jeunes Canadiens ; ils désiraient susciter leurs intérêts, les garder à l'école et les préparer à devenir des travailleurs et des consommateurs une fois leurs études terminées. 
During and following the Second World War, the way in which young people were being educated, as well as the purpose of the public school system itself, was on the minds of many Canadians. Alongside issues such as housing, wages and prices, and veterans' resettlement, education was a key concern when governments at both the provincial and federal levels began planning post-war economic and social initiatives in 1942, well before the end of the war. Many commentators believed schools were vitally important to the future of the country, yet few were satisfied with the current school system. A study of the educational needs of Canada, prepared to assist with post-war planning, identified numerous problems with public education in Canada: many schools were in poor condition or lacked equipment; teachers were underpaid and in short supply; and too many students were either failing to progress through grades, or were leaving school at a young age. ${ }^{1}$ The findings were reported in national newspapers and presented to crowded school council meetings. ${ }^{2}$ Examining the high school curriculum, the authors of the study challenged the notion that "entrance to college is the sole aim of secondary education." ${ }^{3}$ Rather than preparing a select few for university, secondary schools should prepare all young people for satisfactory lives in a modern society. While many concurred that high school needed to be more practical and less academic, there was much debate about what "practical" meant and how precisely secondary school should be transformed into a universal and useful experience for all young Canadians. If schools were to serve a broader function than they previously had, what was this function, and who should have a say in deciding what it was? ${ }^{4}$ In answering this question, educators, administrators, policy-makers, and the public were repeatedly asked to determine what they wanted the schools to accomplish. ${ }^{5}$

While opinions about the purposes of high school were diverse, this paper demonstrates that between 1945 and 1951 representatives of Canadian production and distribution industries played a growing and integral role in curriculum reform. These industry leaders - business and shop owners, factory managers, and members of industry associations - articulated (consciously or not) a new purpose for secondary education: that of preparing students for adult roles as both workers and consumers. To shift schools towards reflecting the capitalist and materialist values of a burgeoning consumer economy, industry leaders joined some educators in defining a form of practical education that: (a) emphasized the value of habits such as dedication and persistence over skilled technical training; (b) embraced courses deemed relevant to post-war problems and subjects believed to appeal to a broad range of students, and (c) included or valued part-time work in the high school experience. As they struggled to define a new program to better fit students' perceived needs, educators and their industrial and commercial partners ascribed a consumer identity to the student, desiring to make high school more palatable and personalized to meet individuals' needs.

The arguments made here stem from a close reading of archival records, published reports, articles in scholarly and popular periodicals, and newspaper reports and editorials. The majority of these documents were generated by one organization, the Canadian Education Association (hereafter CEA). Known initially as the Dominion 
Education Association when it was created in 1891, the organization was led by a council composed of school board superintendents, ministers of education, university and Normal School presidents, and representatives from provincial teachers' associations. The association was formed "for the teachers of the Dominion of Canada," and, in its first few decades, met annually to discuss general issues in education. These included variations among educational standards in different provinces, truancy rates, university extension work, and the establishment of public kindergartens. ${ }^{6}$ Interest in the organization declined in the 1920s, but revived in the mid-1930s with a new focus on producing and sharing educational research across provincial boundaries. In the 1940 s, the CEA created a secretariat with a central office and staff in Ottawa, began publishing a journal, Canadian Education, and secured regular financial contributions from provincial governments to support its work. ${ }^{7}$ It continued to be directed by senior educational administrators and ambitiously sought to spark nation-wide discussion and to act both as a clearing house for research and as a central office through which "educational agencies and voluntary groups may speak with a united voice, co-ordinate their efforts, or help to make education a force for harmony and goodwill within Canada and among the nations."

Between 1943 and 1951, some of the CEA's research focused on the changing role of secondary schools, and this work is the focus of the analysis that follows. In 1946, the CEA set out to determine how well high school curricula (different in each province) were meeting student needs. Partnering with representatives from trade associations, labour unions, and agricultural organizations, it created the Canadian Research Committee on Practical Education. This committee produced several reports between 1947 and 1951, among them an examination of young people's reasons for leaving school before graduation, entitled "Your Child Leaves School," a follow-up study of these former students called "Two Years After School," and a final report optimistically heralding "Better Schooling for Canadian Youth.” These reports generated commentary from and debate among teachers, labour unions, employers, and the media. While individual provinces such as Alberta and Ontario were conducting commissions into the state of education during this time, the CEA's work was different because the organization was a national body attempting to guide and record questions about high school students' needs in disparate parts of the country. Its role in defining and advancing practical education makes it key to understanding the shifting relationship between commerce and the classroom.

The role of the classroom and school curricula in shaping and imparting consumer values has received little historical attention to date. In 2005, sociologist Daniel Thomas Cook argued convincingly that "scholars interested in the lives of children and in the social contours of childhood have remained largely inattentive to the consumer popular culture in which these lives are embedded and out of which particular versions of childhood have arisen." In the ensuing decade, Canadian historians have produced several important histories examining childhood and consumer culture; however, they have only just begun to examine the history of consumer culture in schools. ${ }^{10}$ Robert Gidney and Catherine Gidney's article using teacher magazines to examine advertising in schools is an initial and crucial foray into this subject. ${ }^{11}$ As 
Gidney and Gidney note, at first glance there is relatively little evidence of direct advertising in Canadian classrooms after the Second World War, especially when compared to contemporary North American schools. Consumer education courses may be another way to track particular perspectives on mass consumption; however, many Canadian high schools did not adopt these courses — designed to "empower students in relation to the marketplace, chiefly through the teaching of economics and the development of market-related skills" - until the 1970s, furthering the impression that consumer culture was not part of the classroom before then. ${ }^{12}$

In her classic text, Viviana Zelizer argues that twentieth-century adults redefined children's economic value, separating young people from the marketplace of working and shopping, and investing childhood with sacred emotional values increasingly separate from all things adult. ${ }^{13}$ Schools were leading institutions in this "islanding" of childhood; yet, at the same time, a well-documented youth culture proliferated in high-school hallways from the 1920s onward - young people were clearly consuming the ready-made clothing, beauty products, movies, and cheap amusements that were available to them. ${ }^{14}$ High schools were part of a process of commercial enculturation articulated by Cook, one of many institutions and experiences that engaged children in an ongoing dialogue about their consumer identities and consumption practices. ${ }^{15}$

This paper begins to analyze the participation of business interests in shaping pedagogical priorities and student experiences at the level of policy and educational research. In so doing it builds upon existing interpretations of education policy debates in twentieth-century Canada. ${ }^{16}$ Scholars have most often framed these debates as occurring between educators who favoured progressive education theories and practices and those who preferred traditional or formal subjects and methods. Progressive educators subscribed to a "new education" first articulated by American scholar John Dewey that was child-centred and organized along democratic lines. Progressive Canadian educators in the 1930s and 1940s wanted schools to reflect the concerns of modern society, such as technological change and industrial relations. ${ }^{17}$ Traditionalists, on the other hand, valued classical subjects such as Latin and ancient history, and believed that authoritative teachers needed to use rote learning and exposure to "higher" culture to expand young minds. Historians such as Robert Stamp have argued that from the 1920s onward, both progressive and traditionalist educators pushed their conflicting visions before policy-makers and the public, resulting in pendulum swings between conservative and liberal approaches to education. ${ }^{18}$ Where do advocates of practical education fit into these approaches?

Not all advocates of practical education shared the opinions of progressive educators. Their desire to prepare students to be both employees and consumers in the post-war world was not a progressive one. Indeed, John Dewey argued in 1933 that what he saw as an "acquisitive economic society" was anathema to his vision of democratic education. ${ }^{19}$ Nor did practical education at this time completely adhere to the beliefs of traditionalists. Rather than trying to define the post-war push for practical education as either progressive or traditional, this research focuses instead on the words and deeds of practical education advocates trying to define students' needs. By examining subtle expressions of consumerist values rather than cases of overt 
corporate sponsorship or in-school advertising, this research illuminates the growing relationship between business and educational authorities in Canada in the 1940s.

Three distinct changes highlight the emerging consumerist ethos in debates about reforming high schools to meet students' needs in the immediate post-war years. For one, educators increasingly defined students as consumers of education, as individuals who needed to be interested in the "product" being offered and whose opinion should be solicited when planning curriculum changes. At the same time, a group of employers from a variety of industries participated in and influenced the CEA's research and spoke openly about their interest in making secondary schools more practical. In their view, practical education meant bringing the schools closer to the marketplace. Many wanted to ensure that all students acquired basic economic literacy and an appreciation of consumer capitalism. Finally, employers and educators encouraged teachers and school administrators to value part-time employment as part of a practical education. Industry representatives and allied educators wanted a program that prepared students to be both earners and spenders.

\section{Ask the Industries}

Post-war debates about education involved an unprecedented level of interest and input from Canadian industrialists, company managers, and industry associations. A group of men - no women were invited to participate in these debates - selected from the manufacturing, retailing, resource extraction, and agricultural sectors weighed in about how to define and meet students' needs in post-war secondary schools.

Employers and business owners had taken an interest in education before. In the 1910s and 1920s, for example, firms were involved in developing special courses for new vocational high schools in Ontario's urban and industrial centres. Occasionally, leading businessmen would speak about the future needs of their industry and make comments about the skills they sought in future employees. ${ }^{20}$ However, in the postwar period, the relationship between education and industry was vigorously renewed through the efforts of the Canadian Education Association; the intensity and character of employers' involvement increased as the business community weighed in on the general high school program, rather than vocational training offered to only a few students.

During this period, the CEA invited an increasing number of industry leaders to speak at its annual conventions. Most of these men spoke of the need for increased co-operation between educators and employers. For example, in 1946 the president of Imperial Oil, Henry Hewetson, spoke at the CEA's annual convention. Noting that it was unusual for a business leader to speak at an education conference, he stressed that industry and education were interdependent, and that both needed to "cooperate in the common purpose of building a better and more prosperous democracy." ${ }^{21}$ Whether convention delegates found his presence unusual or not is difficult to say, but in the years that followed, conventions included addresses from the manager of a Canadian sugar manufacturer, a woodworking machinery manufacturer, 
a large pulp and paper manufacturer, the Canadian Chamber of Commerce, and a representative of the Canadian Brotherhood of Railway Employees. ${ }^{22}$

Shortly after Hewetson's 1946 address, a group of industry representatives met with the CEA to discuss a proposed survey related to introducing more practical education in secondary schools. CEA leaders began to forge closer ties between educators and representatives of business, industry, and labour by selecting F. K. Stewart, former industrial relations expert for the pulp and paper industry, as the organization's new executive secretary, and appointing A. G. McColl, a secondary school principal from the mining town of Kirkland Lake, Ontario, as research director for the proposed project. ${ }^{23}$ Proponents of practical education were now positioned to influence the direction of the study.

The creation of the CEA's Canadian Research Committee on Practical Education (hereafter CRCPE) brought increasing attention to and focus on the practical needs of Canadian students and, between its formation in 1946 and its final report in 1951, engaged with industry representatives to set its research agenda and reach its recommendations. In fact, the Financial Times reported in 1948 that the group was created at the behest of, and financed by, industry groups such as the Canadian Retail Federation and the Canadian Manufacturing Association. ${ }^{24}$ Between 1947 and 1951, more than forty firms and groups gave roughly sixty thousand dollars to conduct surveys, compile opinions, and discuss results. ${ }^{25}$ Included on the list of contributors were Canada's leading trade organizations, several large manufacturers of items such as textiles, household appliances, pulp and paper, and steel, as well as numerous mining companies. Several prominent retail grocers and four large department store retailers also contributed financially to the committee's work. ${ }^{26}$

Members of the Canadian Retail Federation, the Canadian Manufacturers' Association, and the Canadian Chamber of Commerce, among others, sat on the CRCPE's board of directors, which determined the course of the committee's research. These groups were also represented on some of the provincial advisory committees that assessed the CRCPE's work. Some of these representatives distributed surveys to different industries - retail, manufacturing, office workers, and construction firms, for example — to ask how high schools could better prepare young people "to take their proper place as efficient workers and good citizens." ${ }^{27}$ The reports they produced (discussed below) concluded that the majority of Canadian teenagers were ill-served by current high school programs and were suffering economically as young adults because of it. They made numerous recommendations to provincial education authorities, urging them to embrace courses that would prepare students not going to university for a life of blue- or white-collar work, marriage and parenthood, home ownership, and steady consumption.

\section{The Student-Consumer}

In the post-war period, discussion about the high school program increasingly referred to students in ways that implied they were consumers of education. Students were not consumers in the sense that they paid money for their education, since 
high schools built and operated by provincial governments did not charge tuition. However, educators and social commentators began in the post-war years to both define and defer to students' needs and to believe that the curriculum - or school product — needed to be tailored both to meet diverse needs and appeal to students' interests.

Secondary students in Canada were a growing group in the post-war years. As war industries converted back to manufacturing for the civilian market and veterans returned from service overseas, an increasing number of teenagers attended and remained in school. Enrollments rose precipitously; in Ontario in the fifteen years following the war, the number of students attending secondary school increased by 141 per cent. ${ }^{28}$ While educators and policy-makers debated the purpose of schooling, many local school boards had difficulty just keeping up with new classroom construction and staffing shortages. ${ }^{29}$

Social and economic conditions had resulted in new regulations that kept young people in school longer in the years following the First World War. Combined with reforms to employment legislation, provincial regulations enacted across the country between 1914 and 1925 raised the minimum age at which children could leave school, and most children were now required to stay in school until age $16 .{ }^{30}$ During the 1930s, the depressed economy and high unemployment rates further encouraged some students to stay in school longer than they had previously. Girls tended to remain in school longer than boys, likely because their best chances in the labour force - as teachers, nurses, or white-collar office workers - required a grade 8 education at a minimum. ${ }^{31}$ Many young men, however, lacked both education and employment. Government statisticians published widely-read and alarming reports about the number of young people who were neither in school nor working. These drifters were viewed as a danger to the social order-susceptible to extreme political ideas because of their youth and ignorance, more likely to be promiscuous, and potentially frustrated at being denied the ability to earn a living and start a family. ${ }^{32}$

The Second World War provided jobs for many, particularly for teenaged boys and girls not old enough to join the army but keen to participate in the war effort, earn money, and achieve adult status. For adults anxious about the effects of the war on Canadian families, schools were seen as contained and stable places for teenagers, and some called for government restrictions on teenaged jobs and curfews to limit potential delinquent behaviour. ${ }^{33}$ Furthermore, the science of warfare, from mass production to radar communications and chemical weapons to atomic energy, suggested to many that the post-war workforce would need to be educated at a more advanced level than the tradesmen and labourers of the past had been. There were simply fewer low- and unskilled jobs for teenagers who left school before graduating. ${ }^{34}$ Although the majority of young people in Canada still did not earn a secondary school diploma by the mid-twentieth century, many Canadians were beginning to believe that secondary school should be part of the basic education required for all young people.

Rising expectations about school attendance and graduation cast those who left school before graduating in a new and problematic light, as educators sought to 
understand and explain high attrition rates. The "drop-out" was the subject of several studies and surveys during the 1940s that concluded that there were multiple and complex reasons why young people left school before completing their secondary program. But much of the blame was placed on schools. The Canadian Research Committee on Practical Education asked students in grades seven to twelve who were leaving school before graduation to list their reasons for doing so (they were allowed to give multiple answers). The most common reasons given were related to the school; 53 per cent of boys' responses and 35 per cent of girls' responses attributed their decision to leave school to the curriculum and subjects studies, to their teachers, to their failure to progress through grades, or to a "lack of interest" in school. Reasons that the committee analysts labelled "Economic," such as a desire to earn money or a need to contribute additional income to their families constituted 26 per cent of boys' responses and 29 per cent of girls' responses. ${ }^{35}$

To some commentators, lack of interest in the secondary course of study justified a quick and substantial curriculum reform that would create a product that would serve a larger number of students. The idea of fitting the school to the child, instead of asking the child to conform to the school, was certainly not a new one; John Dewey made the notion of teaching the "whole child" a hallmark of progressive education in Canada and the United States, and his ideas enjoyed varying support at different points during the twentieth century. ${ }^{36}$ Ontario and other Canadian provinces had created separate high school programs in the 1920s, with academic courses leading to matriculation (and, it was assumed, university) and commercial and vocational schools leading to immediate employment. Special programs for young people with above- and below-average academic abilities were also available in some places. ${ }^{37}$ While such distinct programs gave the illusion of choice, historians Gidney and Millar argue that many students were unable in practice to exercise much choice in selecting a secondary program. Students who did not earn acceptance into the academic program, but had to remain in school until the age of sixteen, often took vocational training if it was available, and dropped out when they could. ${ }^{38}$

What distinguished post-war calls for secondary school curricular changes was the belief that the majority of teenagers were not being served by current program offerings. Despite the existence of some level of technical and commercial programs in urban centres, most students who had the grades to enter an academic program did so, although a large percentage subsequently dropped out. While as many as a quarter of young people may have intended or wished to attend university at the beginning of their high school years, only 3 per cent would actually go on to the universities for which academic courses were necessary. ${ }^{39}$ This meant a large number of high school students were taking subjects such as Latin, ancient history, and "foreign" languages ${ }^{40}$ even though, some educators argued, they would have little use for this knowledge in their adult lives. Instead of segregating students based on vocational aspirations, some educators believed the solution to keep drop-outs in school was not to put them in a special program, but to make the entire course of studies more palatable and profitable for all students. The high school was no longer a "key gatekeeper of the social order," in the words of historian Bob Gidney, and many believed the academic focus 
of high school was old-fashioned and unnecessary in a modern, post-war Canada. ${ }^{41}$

Educators called increasing attention to the teenagers ill-served by secondary schools. In June 1947, the Associated High School Boards of Ontario advocated a better program for "the forgotten boys and girls - that seventy-six percent who enter high school without intent to continue to university." ${ }^{42}$ An editorial in the Globe and Mail deplored the "wastage of ability" created by school leavers who were "the sad cause of so many misfits in business and industry" because the high schools had not fitted them for the working world. ${ }^{43}$ Addressing Toronto's social and economic elite at the Empire Club the following year, Toronto school board director C. C. Goldring estimated that 60 per cent of urban teenagers were not interested in either academic or vocational programs. Goldring stressed: "This group is not composed of misfits, of delinquents, of those who possess low intelligence quotients, nor is it characterized by a low economic status." In other words, Goldring wanted his audience to know that the students themselves were not responsible for their failure to graduate; these students needed courses with "real use values for the student's future occupation or in his life." ${ }^{44}$ Similarly, the CEA noted in its 1943 survey report that "if we wish to have pupils profit in large measure from their studies, the curricula must be reasonably attractive to them. It is the business of the school to make them so." ${ }^{45}$ The schools, not the students, were the problem.

Reformers who sought to improve the curriculum, engage teenagers' interests, and retain more students in school increasingly emphasized the importance of students' opinions, as consumers of education. In the 1940s, youths' opinions about education were increasingly solicited and valued. What did students want to learn? What courses did they find most useful, most interesting? In 1944, the Canadian Youth Commission, a group formed by a coalition of social and community organizations to make policy recommendations concerning Canadians aged fifteen to twenty-four years, surveyed 1,467 young people who had some secondary school education and asked them what they believed the purpose of high school to be, how well they felt school had served them, and what they would have liked to have learned. The Canadian Education Association followed the same strategy to amass data for its recommendations about practical education in high schools, polling drop-outs and attaching substantial weight to their responses. The Ontario government was also concerned about having young people's concerns represented at the Royal Commission on Education that began in 1945, and included potential commission members (all adults) who could "get the youth view." 46 The practice of polling was commonly used in market research prior to the Second World War, and was promoted by advertisers as an adjunct to democratic society that permitted diverse and competing voices to be heard and considered. The use of similar methods to decide what was wrong with public education extended the rhetoric of market research to education, suggesting that students were also consumers who constituted a market and whose opinion was needed to improve the manufacture and distribution of the school product: the curriculum. ${ }^{47}$

An increasing number of educators also advocated, through their boards of education and through the CEA, for a greater choice of courses. The CEA's 1943 
survey report decried the notion that all students should follow the same curriculum. Different courses of study were necessary to attract and keep students' attention. "In a true democracy," the report noted, "all tastes should be met and provision made for all both in quantity and quality of offerings." The CEA called for fewer compulsory courses in secondary schools, "provision for some differentiation" between courses taken by girls and those preferred by boys, and a greater variety of optional courses to allow students to explore and expand their interests and abilities. ${ }^{48}$ In 1950, Ontario educational authorities announced changes along these lines, reducing the number of mandatory courses in the first year of secondary school and offering students the chance to choose three of seven optional subjects. ${ }^{49}$ With similar goals of increased flexibility and choice, the London, Ontario, board of education proposed experimenting with transferable credit, so that students could transfer out of courses they were finding too difficult without losing credit for work already done. The proposed credit system would allow students to graduate from high school with a much higher percentage of self-selected optional courses and fewer compulsory academic courses. ${ }^{50}$ Experimental reforms of the high school program during the 1940s were not numerous, systematic, or widespread, but they were most often conducted with the aim of offering teenagers more choice at schools.

More choice would make school more palatable for teenagers, but would it result in a more useful education? Educators, school administrators, and policy-makers emphasized that schools needed to link education closely to future employment. The Canadian Youth Commission pointed to its survey of former students who claimed they would have liked more business training (in bookkeeping, handling money, and store organization), more practical instruction in housekeeping, child care, and mechanical skills, and more exposure to current events, economic theories, and political philosophies. "The young people of Canada," the commission concluded, "want the schools to get closer to the working world." 51 Students needed to know that "the education acquired is a profitable one and leads to gainful employment." 52 For some commentators, this meant teaching students about different occupations and the skills they required in vocational guidance classes. Increasingly common in Canada's urban high schools in the 1940s, guidance classes were intended to inform students of occupational options, once again seeming to offer them a choice of educational paths. ${ }^{53}$

While those in favour of making the program more practical advocated greater choice for students, emphasizing the student as an active consumer of high school education and experience, some educators and other commentators argued that certain subjects of study had merit even if they did not always appeal to students. One delegate at the 1950 convention of the Canadian Teachers' Federation (CTF) asked whether school curricula should be "judged entirely on whether or not the public is interested?" ${ }^{4}$ Student interest would not ensure that courses were practical: "We venture to comment," the Quebec delegation wrote to the secretary-treasurer of the CTF, "that the school program which is designed to provide students only with what they want, or like, to do, may succeed in keeping them in school longer, but it will not necessarily please any better their future employers." ${ }^{55} \mathrm{~A}$ writer to the Globe and Mail expressed similar concerns about the merit of practical options when noting, 
"boys and girls, being boys and girls ... will take the line of least resistance" and opt out of more rigorous academic classes out of a natural childhood propensity for laziness. ${ }^{56}$ Others claimed that student attrition was unavoidable, especially when the economy was strong and jobs were plentiful. Members of the Quebec teacher delegation argued that "the prospect of earning wages, and of beginning a man's or woman's work in the world will always appeal strongly to a considerable number of young people from the age of 14 on." ${ }^{\prime} 7$ Students were often attracted by the "present advantage of possessing money," rather than the "future advantages to be gained by persistence in his studies," the Saskatchewan teachers noted. ${ }^{58}$ These reactions indicate that some people — particularly teachers - were not willing to interpret the number of drop-outs as an indication of school failure, nor were they willing to concede that young people were educational consumers who needed to be sold on a reformed and improved school product.

\section{Defining Practical Education to Shape the Student-Consumer}

While many participants in post-war educational debates agreed that schools needed to prepare young people to assume adult responsibilities, exactly how to accomplish this task was contested. Did students need a classical education to make them critical thinkers, as academics such as Hilda Neatby believed? ${ }^{59}$ Not according to advocates of practical education, who believed secondary schools should transform students into good workers and good consumers. During the Second World War, advertising and industry rhetoric worked alongside government propaganda to conflate democracy and post-war freedom with free enterprise and consumer capitalism, connecting patriotism to participation in the marketplace. ${ }^{60}$ The work of the Canadian Research Committee on Practical Education suggests that some educators and their marketplace partners believed a more practical education would prepare students, not for specific occupations, but for participation in a consumer society and for the general routines and experiences of work. In this way, CEA General Secretary F. K. Stewart noted as the CRCPE got to work, schools and business together could create "programs of instruction which have more meaning, greater appeal, and greater apparent value to more of the youth of high school age." 61

Many who believed in practical education did not focus on the importance of specific technical skills so much as on teaching students to appreciate and participate in industrial and consumer capitalism. T. H. Robinson, Manager of Industrial Relations at the Canadian International Paper Company, noted the dangers of technical training for specific occupations in his 1950 address to CEA convention delegates. Practical education "may defeat the objective of turning out men and women fully competent to assume their vocational responsibilities." 62 Education that was too specifically vocational was not practical for the vast majority of high school students who would not be occupied in specific skilled trades. Speaking on behalf of the Canadian Chamber of Commerce, businessman F. J. Wescott told the convention in 1949 that "mechanical dexterity ... important as it may be, is not enough for young people leaving school for industry." 63 
Instead, industry leaders argued, schools needed to give students an understanding and appreciation of industrial and consumer capitalism in a post-war world of competing ideologies. In his 1946 address to the CEA convention, Imperial Oil's president, Henry Hewetson, noted the current need of people for "security in which to enjoy liberty and the benefits of a continuously improving standard of living through the availability of more and better goods and services." ${ }^{64}$ In his assessment, schools should prepare individuals both to increase the value and utility of goods (through their work) and to enjoy the benefits of those goods when at leisure. F. J. Wescott also stressed that, in the context of rising tensions between the United States and the Soviet Union after the end of the Second World War, businessmen "have gained a new sense of the importance of the educational system as a basic agency for the transmission to the next generation of the set of values upon which a free society rests." ${ }^{\text {"S }}$ Robinson also mentioned the Cold War and the stark choice between democracy and dictatorship in global relations in his 1950 address. The individual freedoms of democracy, he noted, had to be defended through a sense of collective responsibility learned at school. ${ }^{66}$

When polled by the CRCPE, managers in industrial and commercial firms echoed a desire for practical education of a general, rather than technical, nature. When asked in what way they were dissatisfied with new employees, only 30 per cent of firms surveyed cited "lack of skill in manual or mechanical work." Far more common responses included: "lack of a sense of responsibility" (72 per cent); "inability to think independently and analyze problems" (63 per cent), and "lack of an occupational goal" (46 per cent). ${ }^{67}$ Firms proposed that schools needed to insist on high standards of student work, focus on the "fundamentals of general education" and "stress responsibilities of citizenship in a democracy." ${ }^{18}$ Employees interviewed also stated that the subjects that had been most useful in their jobs were mathematics and English. ${ }^{69}$ To be fit for their future work, students needed a thorough grounding in reading, writing, and arithmetic, according to Canada's manufacturing and retail employers. However, as the CRCPE report, "Two Years After School," noted, "outside of these two courses (English and Mathematics), the subject matter of most courses is not too important in itself" as long as it emphasizes "high standards of performance in all work." ${ }^{\prime 0}$ The implication was again that specific vocational training was only necessary for the smaller number of students pursuing trades. General education that was practical could embrace a wider variety of courses to appeal to students, so long as communication and computation skills were included.

Advocates of practical education proposed courses that could equip students with the "facts of modern industrial life" both in the workplace and the home. Hewetson believed courses in economics, political science, and practical psychology would help students "enjoy more of the material things of life" and "get along more happily together" while "effectively maintaining our liberties." "71 Similarly, Robinson claimed that "economic illiteracy is one of the most unfortunate blind spots in the training of the school," and also called for schools to embrace other subjects, such as "consumer enlightenment," driver training, sex education, and "propaganda analysis." Robinson's recommendations suggested a more democratic model of schooling: 
offering students many options and allowing them to choose among them. These courses would not lead to post-secondary education, but in Robinson's estimation would serve students' needs by preparing them for lives as citizens and consumers in a capitalist economy. ${ }^{72}$

\section{Integrating School and Work: The Practical Value of Part-time Jobs}

Finally, industry leaders and educators paid increasing attention to the potential value of part-time jobs in creating a practical education to suit student needs. Throughout the Second World War, many educators, academics, and social critics had decried part-time employment of teenagers as useless and wasteful. One such critic, sociologist Dr. Samuel Henry Prince of Dalhousie University, blamed "broken schooling" and "high wages paid to youngsters" for rising rates of "Adolescent Delinquency."73 The Canadian Youth Commission also noted the concerns of community groups who believed teenagers were drawn into "blind-alley occupations," and got into trouble because they had "money to burn." ${ }^{\prime 4}$ These attitudes towards student workers persisted into the post-war years. In 1946, syndicated columnist Angelo Patri insisted that teenagers "have enough to do if they keep up to the standards of the classroom without doing outside work," and suggested that the value of money could be taught through chores and a small allowance controlled by parents. ${ }^{75}$ Similarly, the president of the Saskatchewan Teachers' Federation claimed that easy employment turned students' heads away from education:

... the present era of prosperity puts too much money into the students' hands. This gives them ready access to all kinds of entertainment, and thus the school has to compete with an increasing number of rivals for student attention and interest, some more glamorous than education can ever hope to be. ${ }^{76}$

Although some educators and social critics persisted in seeing after-school, weekend, and summer jobs as useless and distracting, during the immediate post-war period, however, the CRCPE moved to give part-time employment educational value, and recommended including it in the general high school course for students not intending to attend university. W. A. Osbourne, vice-president of an Ontario boiler-making firm, told the 1947 CEA convention that opportunities for summer employment "should be an important and intelligently planned part of the student's education and his adaptive process." 77 Responding to the committee's report, "Your Child Leaves School," the Alberta advisory committee of the CRCPE also argued that schools should recognize part-time jobs as "a desirable thing: it should probably be encouraged, even permitting students to miss periods to hold a job."78

"Two Years After School" drew attention to the widespread practice of students working part-time in this period. Of the former students surveyed (which included both early school leavers and graduates), 83 per cent of boys and 64 per cent of girls reported having worked after school or on weekends and holidays during their school days. ${ }^{79}$ These former students came from a variety of economic backgrounds and 
had been enrolled in both academic and vocational/commercial streams. The survey asked several additional questions in order to understand why students worked and the effect that it had on their schooling and their employment after school.

The report concluded that part-time employment during the school years was valuable for several reasons. The survey found that students who held part-time jobs were less likely to leave school before completing their program, suggesting that parttime work was valuable because it could keep students in school. Students leaving the lower grades (who were on average less than a year younger than those who graduated) were only half as likely to have held a part-time job. The authors of "Two Years After School" theorized that part-time income may have supplemented parents' wages and allowed students who worked to remain in school longer. ${ }^{80}$ Part-time work was also seen as valuable in helping young people make the transition into full-time work, since the survey found that a high percentage of young men and women secured their first job after school in the same field as the part-time job they had held. ${ }^{81}$ Finally, the survey reported that former students valued part-time work, with more than 60 per cent of boys and girls saying their experience helped them "learn how to work," roughly half saying it "gave me more self-confidence," and approximately a third reporting that it helped them decide what type of work they wanted to do later. ${ }^{82}$ Academic work in the growing field of vocational guidance supported these findings. ${ }^{83}$ In its final report, "Better Schooling for Canadian Youth," the CRCPE recommended that secondary schools could better retain students by "recognizing the value of part-time work not only as a means of income, but as providing training and experience, and also as assisting the student to make his choice of occupations." ${ }^{84}$ Other educators echoed the committee's recommendations soon after. ${ }^{85}$

While recognizing the value of part-time work as part of a practical education, some wanted the schools to go further and take a more active role in helping students find part-time jobs. "Two Years After School" noted that less than a quarter of students surveyed had secured their first job with any assistance from their school, relying mostly on their own initiative or on friends and relatives. ${ }^{86} \mathrm{Mr}$. Hector Beaupré, director of the Montreal Technical School, advocated the creation of committees "to facilitate placement of students in summer vacation employment," helping students better make the transition from school to work. ${ }^{87}$ Should the schools be tasked with providing job placement services? CRCPE Research Director A. G. McColl formulated his opinion on the matter while attending a meeting of the American Vocational Association on behalf of the CRCPE in 1947. Upon his return he reported in detail about the American practice of giving senior high school students credit for part-time work experience. High schools in Los Angeles, he reported, had teachers dedicated to instruction in work experience, and part-time jobs were "added to their school experience as an important contribution to practical preparation for living and individual development." These jobs were paid and supervised to ensure "verified learning potential for the student," and the Los Angeles schools reported that because students worked during business hours, they had a wider variety of jobs to choose from and were less likely to take less educational evening work. ${ }^{88}$ Many Canadian high school students already had jobs; anecdotal evidence to date shows 
students working in positions ranging from informal childminding or assisting in the family business to formal Saturday sales positions or after-school office work. ${ }^{89}$ But if schools valued part-time work and tried to make it an educational experience for students, they could improve retention rates and vocational guidance, and increase student interest, according to advocates of practical education.

\section{Practical Education: Learning to Earn, Learning to Spend}

During a brief but formative period following the Second World War, Canadian industrial and retail interests worked alongside sympathetic educators to identify and respond to students' needs and promote a more practical purpose for high schools. Faced with high drop-out rates and fears of social disorder heightened by years of depression and war, industry leaders, educators, and policy-makers called for sweeping changes to curricula that would recognize students as consumers of education, and would prepare students to be both workers and consumers in an industrial-capitalist economy.

In attempting to outline a palatable, profitable, and practical education for students, the Canadian Education Association (and related groups such as the Canadian Youth Commission) defined student needs in consumerist terms. Students' interest in school and opinions about their education mattered more at this moment, and formed a crucial part of research conducted to improve education. Students were their schools' consumers. While some argued education needed to appeal more to students, many more industry leaders argued that high schools needed to teach useful but general habits such as dedication, persistence, and clear communication skills. These skills, they believed, would better prepare young people for working life. They wanted more courses to reflect contemporary society, teaching classical economic theory, and more applied consumer economics, among other options. Finally, practical education would integrate students' learning and earning environments by recognizing part-time work as a useful part of the curriculum. Together, advocates of practical education - industry leaders and educators alike - believed that this type of program would increase student retention and better serve the needs of the majority of Canadian teenagers not destined for university.

When it tabled its final report in 1951, the Canadian Research Committee on Practical Education made forty-five recommendations for reforming the country's high schools. "Better Schooling for Canadian Youth" maintained that better schooling meant more practical schooling, with fewer academic requirements and more electives "to suit the varied interests and aptitudes of the pupils," a recognition of part-time work, and an objective - beyond teaching fundamental literacy and numeracy - to understand the political and economic workings of a democratic country. ${ }^{90}$ The report summarized the post-war interest in practical education and presumed to provide provincial education authorities with a way forward.

However, the report did not result in any immediate, widespread, or systemic change in high school curricula in Canada. Several factors prevented the bulk of the committee's recommendations from being implemented. The most formidable 
hurdle was the reality of motivating ten different provincial education authorities to reform secondary schools in the desired way. Ontario and Alberta had conducted their own provincial Royal Commissions on Education, and were working to implement their recommendations. Some administrators believed that the modifications suggested to make education more practical could not easily be added to the existing program. As Ontario's Chief Director of Education, J. G. Althouse, noted: "Vaguely but emphatically, we seem to be in favour of more and more education for everybody. Just what should constitute the more and more we are not agreed upon: still less can we agree upon what should be dropped out to leave room for the many new additions that are suggested." ${ }^{11}$

Furthermore, shortly after the CRCPE tabled its report, voices that favoured preserving and strengthening the academic character and purpose of high schools grew louder. Foremost among them was history professor Hilda Neatby, who wrote a book in 1953 highly critical of any kind of progressive education. So Little for the Mind denounced all attempts to offer students more choice and defended the high school as a place to prepare for advanced university study. It was widely read and reported on. ${ }^{92}$ Likewise, the launch of the Soviet satellite Sputnik in 1957 caused a spasm of concern about the strength of science education in the United States, and politicians and commentators expressed similar worries north of the border, stressing that students needed more academic subjects rather than fewer. At the same time, the creation of new universities and lowered admission standards in the early 1960s meant that more high school students were continuing their education after high school. While movements in some provinces in the 1950s to centralize educational administration and create larger, regional high schools meant that more students did actually attend schools with access to vocational guidance and a wider variety of course offerings than before, the majority of high school students in the 1950s had the same academic program as their peers in the 1940s. ${ }^{93}$

While the moment was fleeting, and politicians' dedication to reform was perhaps fickle, post-war debates about practical education nevertheless provide a crucial example demonstrating how commercial interests contributed to and shaped schools' purposes. Some of the country's leading educational scholars and administrators demonstrated a strong desire to work alongside employers and business leaders to articulate a different set of values - values that subtly but certainly promoted a consumerist ethos to students who were seen as future workers and consumers. Business leaders and industry associations sought to bring high schools more in touch with the needs of the market, and argued that employability and seamless integration into consumer capitalism were goals that students shared with employers. As an example of school commercialism that did not involve direct advertising or product promotion, this history highlights one part of the complex process of commercial enculturation that brought the student as consumer - of school programs, as a wage earner, and as a member of the post-war consumer-based economy - into being. 


\section{Notes}

* I would like to gratefully acknowledge the L. R. Wilson Institute for Canadian History, at McMaster University in Hamilton, Ontario, for supporting my work on this article.

1 Report of the Survey Committee Appointed to Ascertain the Chief Educational Needs of the Dominion (Canadian and Newfoundland Education Association, March 30, 1943).

2 "Doubled Outlay Need of Schools," Globe and Mail, November 24, 1943.

3 Report of the Survey Committee, 38.

4 A. G. McColl, "A Brief Outline of the Research on Practical Education," Canadian Education 3, no. 1 (December 1947): 92.

5 Norman A. M. MacKenzie, "Education: The Shaping and Moulding of the Individual," Canadian Education 3, no. 1 (December 1947): 56.

6 G. E. Malcolm MacLeod and Robert E. Blair, The Canadian Education Association: The First 100 Years, 1891-1991 (Toronto: Canadian Education Association, 1992), 3, 5.

7 Ibid., 16-19. While much of the association's funding came from provincial governments, it also received grants from the Carnegie Foundation and the W. K. Kellogg Foundation for some of its projects.

8 "Canadian Education," Canadian Education 2, no. 1 (October-December 1946): 130. Prior to 1947, the Canadian Education Association was known as the Canada and Newfoundland Education Association. Although Newfoundland did not join Confederation until 1949, the CEA included members from Newfoundland.

9 Daniel Thomas Cook, "The Dichotomous Child in and of Commercial Culture," Childhood 12 (2005): 155.

10 On the participation of Canadian students in consumer culture outside school, see particularly: Cynthia Comacchio, The Dominion of Youth: Adolescence and the Making of Modern Canada, 1920 to 1950 (Waterloo, Ontario: Wilfrid Laurier University Press, 2006), chapters 4, 5, and 6; and E. Lisa Panayotidis and Paul Stortz, "Visual Interpretations, Cartoons, and Caricatures of Student and Youth Cultures in University Yearbooks, 1898-1930," Journal of the Canadian Historical Association, New Series, 19 (2008): 195-227. In the United States, Lisa Jacobson and Kelly Schrum have both examined advertising aimed at schoolboys and girls in the 1920s and 1930s. See Jacobson, Raising Consumers: Children in the American Mass Market in the Early Twentieth Century (New York: Columbia University Press, 2004) and Schrum, Some Wore Bobby Sox: The Emergence of Teen Girls' Culture, 1920-1945 (New York: Palgrave Macmillan, 2004).

11 R. D. Gidney and Catherine Gidney, "Branding the Classroom: Commercialism in Canadian Schools, 1920-1960," Histoire Sociale/Social History 41, no. 83 (November 2008): 345-379.

12 Judith Stamps, "Consumer Education and the Philosophy of Competitive Individualism in British Columbia," BC Studies 83 (Autumn 1989): 68.

13 Viviana Zelizer, Pricing the Priceless Child: The Changing Social Value of Children (New York: Basic Books, 1985).

14 Marta Gutman and Ning de Coninck-Smith describe the "islanding" of childhood that happens as adult and child actors seek to define and experience a "good childhood" in "Introduction: Good to Think With - History, Space, and Modern Childhood," in Designing Modern Childhoods: History, Space, and the Material Culture of Children, ed. Marta Gutman and Ning de Coninck-Smith (New Brunswick, New Jersey: Rutgers University Press, 2008), 4-5. On the participation of students in consumer culture, see particularly: Comacchio, The Dominion of Youth, chapters 4, 5, and 6; and Jacobson, Raising Consumers. 
15 Daniel Thomas Cook, "Commercial Enculturation," in Childhood and Consumer Culture, ed. David Buckingham and Vebjørg Tingstad (Houndmills, Basingstoke, Hampshire: Palgrave Macmillan, 2010), 63-79.

16 See, most recently, Theodore Michael Christou, Progressive Education: Revisioning and Reframing Ontario's Public Schools, 1919-1942 (Toronto: University of Toronto Press, 2012); Amy von Heyking, "Selling Progressive Education to Albertans, 1935-53," Historical Studies in Education 10, nos. 1 and 2 (Spring and Fall 1998): 67-84; Amy von Heyking, Creating Citizens: History and Identity in Alberta's Schools, 1905-1980 (Calgary: University of Calgary Press, 2006).

17 J. Donald Wilson, Robert M. Stamp, and Louise-Phillip Audet, eds., Canadian Education: A History (Scarborough, Ontario: Prentice Hall of Canada, 1970), 374.

18 See, for example, Robert M. Stamp, The Schools of Ontario, 1876-1976 (Toronto: University of Toronto Press, 1982); Wilson, Stamp, and Audet, eds., Canadian Education.

19 Quoted in Jennifer A. Sandlin, Jake Burdick, and Trevor Norris, "Erosion and Experience: Education for Democracy in a Consumer Society," Review of Research in Education 36 (March 2012): 142.

20 Stamp, The Schools of Ontario, 74-96.

21 His address was published in the association's journal. Henry H. Hewetson, "Education and Industry," Canadian Education 2, no. 1 (October-December 1946): 113-119.

22 See Canadian Education 2, no. 1 (October-December 1946) to 5, no. 2 (March 1950).

23 Canadian Education 2, no. 3 (April 1947): 93.

24 "Too Many Kids in Dead End Jobs? Industry Fosters a Plan to Pep up Career Training," Financial Times, February 14, 1948. Copy in File 2-1-3, Volume 13, Canadian Education Association (hereafter MG 28), Library and Archives Canada (hereafter LAC), Ottawa, Canada.

25 The list also included two labour organizations, the Canadian Teachers' Association and the Canadian Home and School and Parent-Teacher Federation. The total amount raised was $\$ 65,010$. "The Canadian Research Committee on Practical Education - Contributors, 1947-1951," June 22, 1951. File 2-1-2, Volume 13, MG 28, LAC.

26 In total, fifty-seven firms and associations contributed to the CRCPE. "The Canadian Research Committee on Practical Education - Contributors, 1947-1951,” June 22, 1951.

27 "Questionnaire to Employers on the Secondary School Requirements of Distributive Business," May 4, 1949. File 126a, Volume 7, MG 28, LAC.

28 R. D. Gidney, From Hope to Harris: The Reshaping of Ontarios Schools (Toronto: University of Toronto Press, 1999), 27.

29 Paul Axelrod, "Beyond the Progressive Education Debate: A Profile of Toronto Schooling in the 1950s," Historical Studies in Education 17, no. 2 (2005): 232.

30 In Canada's most populous province, Ontario, students aged fourteen and fifteen could be released from school if parents demonstrated an economic need. In other provinces, regulations often allowed exceptions in rural areas.

31 R. D. Gidney and Wyn Millar, How Schools Worked: Public Education in English Canada, 1900-1940 (Kingston and Montreal: McGill-Queen's University Press, 2012), 66-67.

32 J. E. Robbins, Census Monograph No. 9: Dependency of Youth. (Ottawa: Dominion Bureau of Statistics, 1937).

33 Jeffrey A. Keshen, Sinners, Saints and Soldiers: Canada's Second World War (Vancouver: UBC Press, 2004), 210-211.

34 Viviana Zelizer discusses the decline of children's labour in the United States in Pricing the Priceless Child, 62-63. 
35 Eighteen per cent of boys and 25 per cent of girls responding to the survey did not give any reasons for leaving school. The remaining responses ( 15 per cent of boys' reasons and 17 per cent of girls' reasons) were related to "Personal Reasons," such as "Attitude of Parents," "Good Position Open," "Sickness," and "Others." Canadian Research Committee on Practical Education, "Better Schooling for Canadian Youth," Canadian Education 6, no. 4 (September 1951): 32.

36 Stamp, The Schools of Ontario; Axelrod, "Beyond the Progressive Education Debate."

37 Axelrod, "Beyond the Progressive Education Debate," 236.

38 Gidney and Millar, How Schools Worked, 248-249.

39 Ibid., 248.

40 As Gidney and Millar note, many secondary schools outside Quebec offered two "foreign" languages, one of which — French — was not a foreign language in Canada, and the other - Latin - was a language spoken by no foreigner. Gidney and Millar, How Schools Worked, 246.

41 Gidney, From Hope to Harris, 16.

42 "Seek Education for Non-Matriculants," Globe and Mail, June 17, 1947.

43 "Wastage of Ability," Globe and Mail, May 30, 1947.

44 C. C. Goldring, "Are the Schools Preparing Youth to Take Over?" Speech at the Empire Club, November 4, 1948; http://speeches.empireclub.org/60397/data?n=10, accessed February 2, 2014.

45 Report of the Survey Committee, 39.

46 Correspondence between Education Minister Dana Porter and Premier Leslie Frost, quoted in Stamp, The Schools of Ontario, 1876-1976, 187.

47 Daniel J. Robinson, "Polling Consumers: The Rise of Market Research Surveys in Canada, 1929-1941," Journal of the Canadian Historical Association/Revue de la Société historique du Canada 8, no. 1 (1997): 187-211.

48 Report of the Survey Committee, 41.

49 "Cut Number of Compulsory School Subjects," Globe and Mail, March 1, 1950.

50 "The Modern School," address to the Urban School Trustees Association (May 27, 1947), 2. File 6-9, Volume 10, MG 28, LAC.

51 Canadian Youth Commission, Youth Challenges the Educators (Toronto: The Ryerson Press, 1946), 10-11.

52 Ibid., 86.

53 Stamp, The Schools of Ontario, 197.

54 Letter from George G. Croskery, Secretary-Treasurer of the Canadian Teachers' Federation, to F. K. Stewart, Canadian Research Committee on Practical Education, October 16, 1950, 3. File 126a, Volume 7, MG 28, LAC.

55 Ibid., 4.

56 Michael Roth, "Education to Nourish the Mind," Globe and Mail, June 15, 1950.

57 Croskery to Stewart, 3.

58 Ibid., 6.

59 Hilda Neatby, So Little For the Mind (Toronto: Clarke Irwin, 1967).

60 Graham Broad, A Small Price to Pay: Consumer Culture on the Canadian Homefront, 1939-1945 (Vancouver: UBC Press), 108-114. See also Lizabeth Cohen, A Consumers' Republic: The Politics of Mass Consumption in Postwar America (New York: Vintage, 2003).

61 “Too Many Kids in Dead End Jobs?” Financial Times, February 14, 1948.

62 T. H. Robinson, "More Work for the Schools," Canadian Education 5, no. 2 (March 1950): 49.

63 F. J. Wescott, "Education and the Businessman in Canada," Canadian Education 4, no. 4 (September 1949): 35. 
64 Henry H. Hewetson, "Education and Industry," Canadian Education 2, no. 1 (October-December 1946): 117.

65 Wescott, "Education and the Businessman in Canada," 35.

66 Robinson, "More Work for the Schools," 61.

67 "Drop-outs," 2. File 126a, Volume 7, MG 28, LAC.

68 Ibid.

69 Canadian Research Committee on Practical Education, "Two Years After School," 56-58.

70 Ibid., 20.

71 Hewetson, "Education and Industry," 118.

72 Robinson, "More Work for the Schools," 53, 44. Sex education was also much debated in the post-war period; while many educators believed that it was the responsibility of parents to discuss sexual relationships with their children, a growing number were calling for more health education for students. See Mary Louise Adams, The Trouble with Normal: Postwar Youth and the Making of Heterosexuality (Toronto: University of Toronto Press, 1997).

73 Samuel Henry Prince, "The Canadian Family in Wartime," Marriage and Family Living 4, no. 2 (Spring 1942): 27.

74 Rebecca Prigert Coulter, "Schooling, Work, and Life: Reflections of the Young in the 1940s," in Rethinking Vocationalism: Whose Work/Life Is It? (Toronto: Our Schools/ Ourselves Education Foundation, 1992), 71.

75 Angelo Patri, “Teach Youngsters Art of Handling Money,” Globe and Mail, November 26, 1946.

76 Croskery to Stewart, 6.

77 W. A. Osbourne, "Opportunities for Young Men and Women in Canada," Canadian Education 3, no. 1 (December 1947): 91.

78 "Minutes of the Alberta Advisory Committee of the Canadian Research Committee on Practical Education," September 26, 1950, 4. File 126a, volume 7, MG 28, LAC.

79 Canadian Research Committee on Practical Education, "Two Years After School," 23.

80 Ibid.

81 Ibid., 63.

82 Ibid., 64.

83 The CRCPE cited the work of Christopher Sower at Michigan State College, who argued part-time work helped students choose their ultimate occupation. The committee sent representatives to conferences in the United States to learn more about students' experiences with school-supervised part-time work. See A. G. McColl, "Report of the A.V.A. Convention at Los Angeles, Dec. 15-18, 1947." File "Summaries of Books and Pamphlets, etc.," Volume 10, MG 28, LAC. Graduate dissertations in Canada completed around the same time also investigated these subjects. See, for example, William Harrison Lucow, "The Guidance Value of Trips to Industry” (M.A. thesis, University of Ottawa, 1950).

84 Canadian Research Committee on Practical Education, "Better Schooling for Canadian Youth," Canadian Education 6, no. 4 (September 1951): 14.

85 See, for example, the discussions of the urban education group at the 1951 CEA Annual Conference, which noted the "desirability of a program of part-time schooling and part-time work." Canadian Education Association, "Summaries of Conferences: Curriculum," Canadian Education 7, no. 1 (December 1951): 72.

86 CRCPE, "Two Years After School," 65.

87 "Co-operation of Education with Industry, Business, Agriculture, and Labour," Canadian Education 3, no. 4 (September 1948): 112.

88 McColl, "Report of the A.V.A. Convention at Los Angeles," 5. 
89 Evidence of teenaged employment in Canada in the 1940s and early 1950s is currently fragmentary. See Comacchio, Dominion of Youth, chapter 5, for a discussion of young labourers prior to this period. Neil Sutherland uses oral history to examine paid and unpaid child labour in Vancouver in Growing Up: Childhood in English Canada from the Great War to the Age of Television (Toronto: University of Toronto Press, 1997), 113-142. Miriam Forman-Brunell documents the emergence of babysitting as an occupation for teenaged girls in Babysitter: An American History (New York: New York University Press, 2009).

90 CRCPE, "Better Schooling for Canadian Youth."

91 Hugh A. Stevenson, "Developing Public Education in Post-War Canada to 1960," in Wilson, Stamp and Audet, eds., Canadian Education: A History, 387.

92 Neatby, So Little For the Mind.

93 Robert M. Stamp, "Growing Up Progressive? Part II: Going to High School in 1950s Ontario," Historical Studies in Education 17, no. 2 (September 2005): 321-331. 